\title{
Theory and Practice of Informatization in Labor Standardization at Enterprises
}

\author{
I.V. Bogatyreva ${ }^{1, *}$, L.A. Ilyukhina ${ }^{1}$, I.N. Makhmudova and L.V. Polynova ${ }^{1}$ \\ "Corresponding author: scorpiony70@mail.ru \\ ${ }^{1}$ Samara State University of Economics, Samara, Russia
}

\begin{abstract}
The relevance of the studied problem is caused by the increased requirements of employers to reduce production costs (works) including labor expenses. Development of Information Technologies in work standardization gives a possibility to reduce labor input of specialists in work standardization and to increase efficiency of their working hours. It will allow analyzing existing standards in more details and developing activities, which are aimed at increase in their quality. The research objective is to define the main directions of application of the information technologies (IT) in labor rationing. Authors analyzed the experience of IT application to solve the tasks in the field of labor organization and rationing at the enterprises of the Samara region, the structure of organization information system and labor rationing is presented, the approximate work content of time study engineers is given and the structure of its automated workplace is demonstrated. The materials of the article can be useful for the departments of labor rationing, for the research on increasing labor productivity, for the creation of information programs on calculating labor productivity.
\end{abstract}

Keywords: labor rationing, labor norms, information technologies, automated workplace.

\section{Introduction}

Increase in the role of work standardization as the most important function of production management is one of factors of management of labor productivity in modern Russia. Today in the Russian Federation the limits in organization of salary are almost lifted. It eliminates obstructions for improvement of work standardization. Nevertheless, practice and results of studies, which were conducted by the research institute of labor and social insurance in organizations of different types of economic activity, show that the standardization level in Russia has decreased.

At the expense of large volumes of processed information labor rationing is rather labor-intensive process. Now, during the era of computer and information technologies, it has become possible to automate the main works on labor rationing. Use of information technologies allows reducing time significantly that is spent on receiving any service and it is a perspective tendency for labor rationing [1]. The automated production systems have the greatest value for crossdisciplinary research to which labor rationing belongs [2].

\section{Problem Statement}

Russian enterprises accumulated certain experience of automation of work standardization. However, the coverage of works as automated rationing of engineering procedures is insufficient ( $5-7 \%$ of technological labor input). One of the reasons for it is lack of performance coordination on software creation and application that leads to unjustified dispersion of forces, and works duplication. Automation of economic processes leads to decrease in complexity of a production task [3]. The issue of suitable software of different industries has become crucial. To accumulate software in a centralized way and to provide the enterprises and the organizations in a labor scientific research institute, interindustry fund of algorithms and design programs of labor norms and standards was created.

Despite widespread introduction and application of automated information systems in the Russian economy, labor rationing wasn't automated at most enterprises: account and reporting of labor rationing, analysis of the conditions of labor rationing, development of schedules of norms revision, decrease of labor production coefficient and control over their performance. Studying the conditions of automation in labor rationing at a number of industrial enterprises of the Samara region allows estimating its level. The automated labor information processing systems at the enterprises are connected with the performance regarding salary accounting.

Therefore, the expediency of development of information technologies is one of the factors of improvement of work standardization and increase in labor productivity of employees at Russian enterprises. 


\section{Research Questions}

Scientific works of many Russian scientists among which it is possible to mark out R.P. R.P. Miuskova, L.E. Kireeva [4], V.A. Shchekoldin, I.V. Bogatyreva, L.A. Ilyukhina [5] are devoted to a research of automation issues of labor rationing.

The development of information and communication technologies allows increasing labor productivity [6] and reduces labor input of specialists in work standardization and increases efficiency of use of their working hours [5]. It goes without saying that modern computer technologies, applied for development of work standards allow increasing quality and reducing labor input of their development. They accelerate calculation processes of standards of time and output quota on new products, preparation of reporting on a condition of work standardization and the quality of existing standards. In this regard there is a need of consideration of work standardization at an enterprise as the process integrated into activity of a company [7].

Besides specialized programs, complex HRM systems are applied to solve local problems of labor rationing (human resource management - English "management of human resources"). As an example it is possible to name: "BOSSKadrovik", "Monolith: Personnel", "Global-HRM", "Compass: Human resource management", "Alfa: Human resource management subsystem" and other domestic and foreign systems.

\section{Purpose of the Study}

The aim of the research is to define the main tendencies of IT application in labor rationing. The leading approach to the research of this issue is the automation of processes on time standards and production output that allows reducing labor coefficient of time study engineers and increasing rationality of their working hours. To achieve the goal during the research the following tasks were solved:

- the experience of IT application in the field of the organization and labor rationing at the enterprises of the Samara region is analyzed;

- the structure of an information system on organization and labor rationing is presented;

- the approximate content of worker's performance in labor rationing and structure of its automated workplace are given;

- the order and methods of automated systems development of labor rationing are proved;

- the method of calculation of economic efficiency of labor rationing at the automated systems is developed.

\section{Research Methods}

As the practice and scientific research demonstrate the following methods of IT application in labor rationing are possible:

1. Automation of calculation of standards for output.

Automation of calculation is based on use of the analytical calculation method of standardization, which is built on use of developed technological process and the corresponding standard materials (time standards) for work standardization.

2. Development of standard materials for work standardization

Nowadays scientifically based microelement time standards for certain motions and their universal complexes became widely used in practice. They allow analyzing labor organization rather fully and also determining the most rational content of the labor process, methods of its performance, arrangement and maintenance of a workplace in order to lay them in standards.

3. Calculation of optimum norms of service and quantity with use of economic and mathematical methods.

The problem of establishment of optimum service time standards and staffing number standards is to find the most effective ratio between the number of the equipment (or jobs) and the number of workers which serve them. These tasks are multiple, they are solved using mathematical methods, in particular a waiting-line theory.

4. Study of expenditures of working hours and labor processes.

The purposes of studying working hours and labor processes are the following:

- measurement of factual work time expenditures as the basis for establishment of standards and for development of the standard materials,

- analysis and designing of methods and rational ways of work performance,

- recognition of losses and irrational work time expenditures, development of activities on improvement of its use.

5. Analysis of a condition of work standardization

The state of labor rationing is assessed by a number of indicators on which accounting and the reporting are kept at the enterprise. It is possible to allocate the following groups of indicators:

1) quality indicators of existing rules;

2) indicators of labor rationing;

3) the indicators characterizing work organization on labor rationing; 
4) the indicators characterizing scales and efficiency of change and revision of standards.

\section{Findings}

\subsection{State of automation of work on labor rationing at industrial companies of Samara}

Now at the Russian industrial enterprises the certain experience of information technologies application is already accumulated to solve the tasks in the field of labor organization and rationing (Table 1).

Table 1. State of automation of work on labor rationing at industrial companies of Samara

\begin{tabular}{|c|c|c|}
\hline \multirow[b]{2}{*}{$\begin{array}{l}\text { Business } \\
\text { name }\end{array}$} & \multicolumn{2}{|l|}{ Estimation criteria } \\
\hline & Automation object & $\begin{array}{l}\text { State of automated calculation } \\
\text { system on labor }\end{array}$ \\
\hline $\begin{array}{l}\text { Samara } \\
\text { enterprise } 1\end{array}$ & $\begin{array}{l}\text { Accounting of labor input of goods; calculation } \\
\text { of authorized personnel; calculation of average } \\
\text { labor grade of core and auxiliary production; } \\
\text { handling of documents, coming from different } \\
\text { subdivisions; maintenance of normative } \\
\text { documentation }\end{array}$ & $\begin{array}{l}\text { There is practically no AS of } \\
\text { calculation of standards. The } \\
\text { capabilities of computer } \\
\text { technology are not used to the } \\
\text { full extent. }\end{array}$ \\
\hline $\begin{array}{l}\text { Samara } \\
\text { enterprise } 2\end{array}$ & Maintenance of normative documentation & $\begin{array}{l}\text { There are no special } \\
\text { automated programs on } \\
\text { calculation of standards }\end{array}$ \\
\hline $\begin{array}{l}\text { Samara } \\
\text { enterprise } 3\end{array}$ & $\begin{array}{l}\text { Accounting of price and time wages, bonuses, } \\
\text { additional payments and accidental benefits; } \\
\text { calculation of average earnings; reassessment of } \\
\text { benefits and perks; calculation of deductions from } \\
\text { wages of workers; accounting of subsist; } \\
\text { accounting of pension for working pensioners; } \\
\text { preparation of record development according to } \\
\text { all criteria of accounting of labor and wages; } \\
\text { completing forms of statistical reporting }\end{array}$ & $\begin{array}{l}\text { AS of data processing is only } \\
\text { related to organization of } \\
\text { work on payroll accounting. } \\
\text { There is no AS of labor } \\
\text { rationing }\end{array}$ \\
\hline $\begin{array}{l}\text { Samara } \\
\text { enterprise } 4\end{array}$ & $\begin{array}{l}\text { Accounting of piece-rate wages; recording of } \\
\text { production runs of pieceworkers and performed } \\
\text { operations during the base period; planning and } \\
\text { recording of working time for all categories of } \\
\text { workers; evaluation of labor input of goods; } \\
\text { assessment of main workforce size; evaluation of } \\
\text { production load; determination of planned and } \\
\text { actual volumes of subdivisions; calculation of } \\
\text { production capacity; product costing; performing } \\
\text { technical-economic and production scheduling } \\
\text { calculations }\end{array}$ & $\begin{array}{l}\text { AS of data processing is quite } \\
\text { powerful: it is intended both } \\
\text { to automation of labor } \\
\text { rationing and payroll } \\
\text { accounting. However, } \\
\text { available software is morally } \\
\text { and physically outdated }\end{array}$ \\
\hline
\end{tabular}

Source: compiled by the authors.

\subsection{The results of photos of the working day of a labor specialist}

The objects of automation at the enterprise are the works performed by specialists in labor rationing. Depending on the level of management (the enterprise, units) and functional differentiation of labor between experts in subdivisions, objectives and functions in the field of labor rationing are ranged and concretized in duty regulations.

Determination of expediency of automation as well as detection of the correspondence of the list and the complexity level of the performed work with duty regulations of a specialist in work standardization is possible only by the results of analysis.

Photographs or self-photographs of the working day of labor specialists should be taken within a week or a month. The analysis of the research results of expenses of working hours will allow us to draw conclusions on the structure of the performed work in a subdivision. The results of photos of the working day of a labor specialist at one of the Samara enterprises are presented in table 2 as an example. The main part of the working day of a specialist in labor can be attributed to work on report preparation $(24,2 \%)$ and carrying out observations $(20 \%)$.

Table 2. Total balance of working hours of a specialist in labor according to photos of the working week

\begin{tabular}{|l|c|c|}
\hline \multicolumn{1}{|c|}{ Name of work } & \multicolumn{2}{c|}{ Duration } \\
\cline { 2 - 3 } & minutes & $\%$ of total \\
\hline Reconsideration of standards & 110 & 4,6 \\
\hline Calculation of new standards & 270 & 11,2 \\
\hline Taking photographs of the working day and conduction of stop-watch reading & 480 & 20,0 \\
\hline Processing of photographs of the working days and stop-watch reading & 120 & 5,0 \\
\hline
\end{tabular}




\begin{tabular}{|c|c|c|}
\hline Completion and checking of work orders & 290 & 12,1 \\
\hline Contacts with masters and technologists regarding labor issues & 180 & 7,5 \\
\hline Organizational work and operational meetings & 120 & 5,0 \\
\hline Delivery of documents to the Labor and Remuneration Management Department & 50 & 2,1 \\
\hline Work stoppages & 200 & 7,3 \\
\hline Compilation of a report on fulfillment of standards, structure of salary, etc. & 580 & 24,2 \\
\hline Total & 2400 & 100,0 \\
\hline
\end{tabular}

Source: compiled by the authors.

The automation of a workplace (AWP) of a specialist in work standardization should be oriented to solution of various functional tasks in work organization and standardization at all levels of management. At the level of an enterprise, the structure of an automated workplace should include works on the analysis of a condition of labor standardization, development of work standards, calculation of labor input of products and drawing up plans for its decrease, analysis of reasons and identification of guilty persons for downtime, preparation of reporting, etc. At the level of a shop, a subdivision - there are absolutely another works.

\subsection{The amount of work of a labor specialist is subject to automation}

On the basis of duty regulations on work standardization and analysis of work content of a specialist in labor in a subdivision, the scope of work is made. Their performance is subject to automation:

- setting of standards on new detail-operations on the basis of time standards, and on observational and statistical data;

- formation of the data base of standards and wage-rates and other reference data;

- processing and analysis of results of photographs of the working day and stop-watch reading;

- calculation of labor input of goods for nomenclature of the annual production program;

- account of performance of standards on certain employees, professions, brigades, sectors, subdivisions;

- analysis of a condition of standardization;

- development of scheduled plans of replacement and reconsideration of standards, control after it performance;

- preparation of reporting on performance of standards, decrease in labor input, expenditure of the wages fund [8].

\subsection{Labor input of performance of work on labor rationing}

Development and implementation of the automated system of labor rationing lead to economy of working hours both in the sphere of production, and in the management sphere. Labor productivity increases that influences production efficiency both at the micro- and at the macrolevel [9]. As calculations showed, automation of work on labor rationing is rather effective (Table 3).

Table 3. Labor input of performance of work on labor rationing in the shopfloor

\begin{tabular}{|c|c|c|c|c|c|}
\hline Activities & $\begin{array}{l}\text { Quantity } \\
\text { per year }\end{array}$ & $\begin{array}{r}\text { Labo } \\
\text { ac } \\
\end{array}$ & $\begin{array}{l}\text { nput of one } \\
\text { ity, hour }\end{array}$ & Annuc & $\begin{array}{l}\text { bor input, } \\
\text { ur. }\end{array}$ \\
\hline & & Manual & $\begin{array}{c}\text { In automatic } \\
\text { mode }\end{array}$ & Manual & $\begin{array}{c}\text { In } \\
\text { automatic } \\
\text { mode }\end{array}$ \\
\hline Calculation of new & & & & & \\
\hline standards & $\begin{array}{l}2060 \\
1835\end{array}$ & 0,5 & $\begin{array}{l}0,05 \\
002\end{array}$ & 1030 & $\begin{array}{l}103 \\
37\end{array}$ \\
\hline Compilation of a report on & & & & & \\
\hline fulfillment standards & 12 & 4,0 & 0,2 & 48 & 2,4 \\
\hline $\begin{array}{l}\text { Compilation of a report on } \\
\text { reduction of labor input }\end{array}$ & & & & & \\
\hline $\begin{array}{l}\text { Report on financial results } \\
\text { of activity }\end{array}$ & 4 & 8,0 & 0,3 & 32 & 1,2 \\
\hline Logging(filing) of standards & 4 & 2,5 & 0,15 & 10 & 0,6 \\
\hline & 5530 & 0,14 & 0,01 & 774 & 55 \\
\hline Total & & & & 2187 & 199 \\
\hline
\end{tabular}

Source: compiled by the authors according to the research results.

The carried out research shows that under the conditions of full, limited, individual production specialists in labor rationing spend up to $70 \%$ of their working hours for setting standards. Automation of work on labor rationing allows facilitating considerably work of time study engineers, reducing labor input and increasing rationality of use of their working hours. In organization of labor rationing, where the number of time study engineers tends to reduction in recent years, efficiency of use of these technologies enables to increase labor productivity by $5-7$ times. 


\section{Conclusion}

In modern conditions when market relations and the competition between enterprises develop and deepen, stability of their economic status can be provided by continuous decrease in all types of production expenses, including labor costs. Growth of labor productivity can be provided also due to decomposition of flow processes on microelements [10]. That is why improvement of labor rationing should be the most important element of management; it should not only deal with enhancement of staffing, regular revision of norms and standards, regulatory and methodological basis, but also provide wide application of information systems on the basis of modern computer technologies. Now, when scientific-technological progress flourishes, only enterprises, which are regularly updating their technical, information base and applying the latest computer technologies, including labor rationing, can be effective and competitive in the market. Studying of various references and experience of a number of enterprises showed that this problem in Russia is insufficiently elaborated. Despite widespread implementation and use of the automated information systems at the enterprises, for the purpose of labor rationing, the flexible software Microsoft Office is generally applied to the solution of local tasks. At the majority of enterprises, automation does not cover the whole complex of problems of labor rationing. Thus, the integrated system of automation of work, offered by us, is an important tendency in improvement of labor rationing at the enterprises in modern conditions.

\section{References}

1. M. Savona, W.E. Steinmueller, Service output, innovation and productivity: A time-based conceptual framework. Structural Change and Economic Dynamics, 27, 118-132. DOI: 10.1016/j.strueco.2013.06.006 (2013).

2. B. Vogel-Heuser, A. Fay, I.Schaefer, M. Tichy, Evolution of software in automated production systems: Challenges and research directions. Journal of Systems and Software, 110, 54-84. DOI: 10.1016/j.jss.2015.08.026 (2015).

3. A. Beck, P. Göhnera, Models for model-based user-centric energy analysis of industrial automation systems. Procedia Computer Science, 6, 423-428. DOI: 10.1016/j.procs.2011.08.080 (2011).

4. R.P. Miuskova, L.E. Kireeva, Development and renewal of time rates by means of method of index numbers. Norm Setting and Remuneration of Labor in the Manufacturing Industry, 4, 59-65 (2013). [in Rus.].

5. V.A. Shchekoldin, I.V. Bogatyreva, L.A. Ilyukhina, Use of information technologies in labor standardization. Labor Economics, 5(1), 34-39 (2018). [in Rus.].

6. V.A. Vaisburd, M.V. Simonova, I.V. Bogatyreva, E.G. Vanina, E.P. Zheleznikova, Productivity of labour and salaries in Russia: Problems and solutions. International Journal of Economics and Financial Issues, 6(S5), 157-165 (2016).

7. O.V. Shutina, Labor standardization as a business-process. Vestnik of Omsk University. Series Economics, 2, 19-25 (2009). [in Rus.].

8. V.A. Schekoldin, I.V. Bogatyreva, L.A. Ilyukhina, V.M. Kornev, Development of IT-technologies in labor standardization and quality assessment of standards: challenges and ways of solution in Russia. Helix, 8(5), 36153628. DOI: 10.29042/2018-3615-3628 (2018).

9. G. Lanza, J. Stoll, N. Stricker, S. Peters, C. Lorenz, Measuring global production effectiveness. Procedia CIRP, 7, 31-36. DOI: 10.1016/j.procir.2013.05.006 (2013).

10. J.R. Baldwin, W. Gu, B. Yan, Export growth, capacity utilization, and productivity growth: Evidence from the Canadian manufacturing plants. Review of Income and Wealth, 59(4), 665-688. DOI: 10.1111/roiw.12028 (2013). 